\title{
Penerapan Data Mining Dalam Mengklusterisasi Location Best Pb Tambahan Pada Regional IV PT Indomarco Prismatama Cab.Medan Dengan Menggunakan Metode K-Means
}

\author{
Annisa Fitri, Yohanni Syahra, Rini Kustini
}

Sistem Informasi, STMIK Triguna Dharma

\begin{tabular}{l}
\hline \hline Article Info \\
\hline Article history: \\
Received Jun $12^{\text {th }}, 2020$ \\
Revised Aug $20^{\text {th }}, 2020$ \\
Accepted Aug $26^{\text {th }}, 2020$
\end{tabular}

\section{Keyword:}

Area

K-Means

Cluster

Pengelompokan

Produk

\begin{abstract}
Permintaan barang merupakan hal yang sangat penting bagi PT Indomarco Prismatama dalam pemenuhan kebutuhan stok toko. Pemenuhan stok yang tepat sangat berpengaruh besar untuk pendapatan laba yang besar bagi perusahaan. Salah satu hal penting lainnya yang perlu diperhatikan adalah area atau daerah persebaran toko indomaret dalam menjual produknya. Apalagi Indomaret merupakan perusahan yang bergerak di bidang ritel dalam penjualan kebutuhan pokok, sehingga perusahaan tersebut juga harus memperhatikan daerah yang memiliki potensi jual yang paling besar.

K-Means Clustering merupakan salah satu metode dari data mining untuk pengelompokan suatu kasus ke dalam tiap kelas yang dihitung dengan konsep sebuah iterasi secara berulang untuk mendapatkan sebuah nilai rasio dimana akan dihentikannya perhitungan iterasi ketika nilai rasio tidak lagi lebih besar dari nilai rasio sebelumnya. Metode ini menggunakan rumus Euclidian sehingga ditemukan jarak yang paling dekat dari setiap data dengan centroid. Apabila salah satu cluster atau kelompok memiliki banyak data area, maka area di salah satu cluster itu merupakan kelompok area permintaan paling besar yang terpilih berdasarkan perhitungan K-Means Clustering.

Dengan membangun sebuah sistem dalam penelitian ini, yang dimana dalam penelitian ini menghasilkan sebuah ilmu pengetahuan baru yaitu mengetahui daerah atau area mana yang paling besar dalam pemenuhan $\mathrm{pb}$ tambahan yang diharapkan nantinya berguna bagi perusahan untuk dapat memaksimalkan sistem pemenuhan $\mathrm{pb}$ tambahan.
\end{abstract}

Copyright (C) 2020 STMIK Triguna Dharma. All rights reserved.

First Author

Nama : Anisa Ftiri

Program Studi : Sistem Informasi

STMIK Triguna Dharma

Email: anisafitri0828@gmail.com

\section{PENDAHULUAN}

Data mining adalah suatu proses pengolahan data yang memiliki tujuan untuk menggali, mendapatkan dan menemukan sebuah pengetahuan yang tersembunyi dari sekumpulan data dalam ukuran besar disebut data mining dan dalam artian lain data mining merupakan sebuah teknik baru dalam menganalisis sejumlah data yang besar untuk mendapat sesuatu hal yang baru [1].

Clustering atau yang lebih dikenal dengan sebutan analisis cluster merupakan suatu proses pengelompokan satu set benda terlihat ataupun tidak ke dalam satu kelas objek yang sama dan di dalam clustering, terdapat banyak teknik-teknik yang digunaka, salah satunya adalah dengan menggunakan Algoritma K-Means Clustering [2].

PT Indomarco Prismatama atau yang lebih dikenal dengan sebutan Indomaret merupakan sebuah perusahan ritel nasional waralaba terbesar di Indonesia dengan tujuan mendapatkan target pasar yang besar 
mulai dari kalangan masyarakat yang ada di Indonesia. Masalah yang terjadi pada perusahaan adalah dalam pemenuhan stok toko khususnya pada pb tambahan atas produk tertentu sering terjadi over stok ataupun stok kurang dikarenakan stok yang dipenuhi terkadang tidak sesuai dengan penjualan yang terjadi di daerah toko yang meminta stok pb tambahan.

$\mathrm{Pb}$ (Permintaan Barang) merupakan sebuah sistem yang digunakan oleh PT Indomarco Prismatama khususnya departemen Distribution Center dalam memenuhi kebutuhuan toko. Hal ini digunakan untuk menunjang stok toko atas item-item atau produk tertentu yang memiliki nilai jual tinggi sehingga apabila pemenuhan sudah sesuai maka dapat mempengaruhi pendapat seles toko yang besar dan juga provit laba yang besar pula bagi perusahaan.

K-Means adalah sebuah metode dalam clustering yang memiliki sifat non hierarki dan berusaha mempartisi data yang ada ke dalam bentuk satu atau lebih cluster dalam arti lain kelompok sehingga data yang memiliki karakteristik yang sama akan dikelompokkan kedalam cluster yang sama dan data yang berbeda dikelompokkan ke cluster yg lainnya [3].

\section{KAJIAN PUSTAKA}

\subsection{Data Mining}

Suatu pola yang digunakan untuk menemukan hubungan antar item sehingga membentuk pola pengetahuan yang baru dalam data yang besar dan dapat diselesaikan menggunakan teknik tertentu seperti ilmu statistik, dan matematika disebut juga sebagai pengertian data mining menurut [4].

\subsubsection{Tahap-Tahap Knowledge Discovery In Database}

Proses KDD (Knowledge Discovery Databases) secara garis besar dapat dikemukakan sebagai berikut menutut [5] :

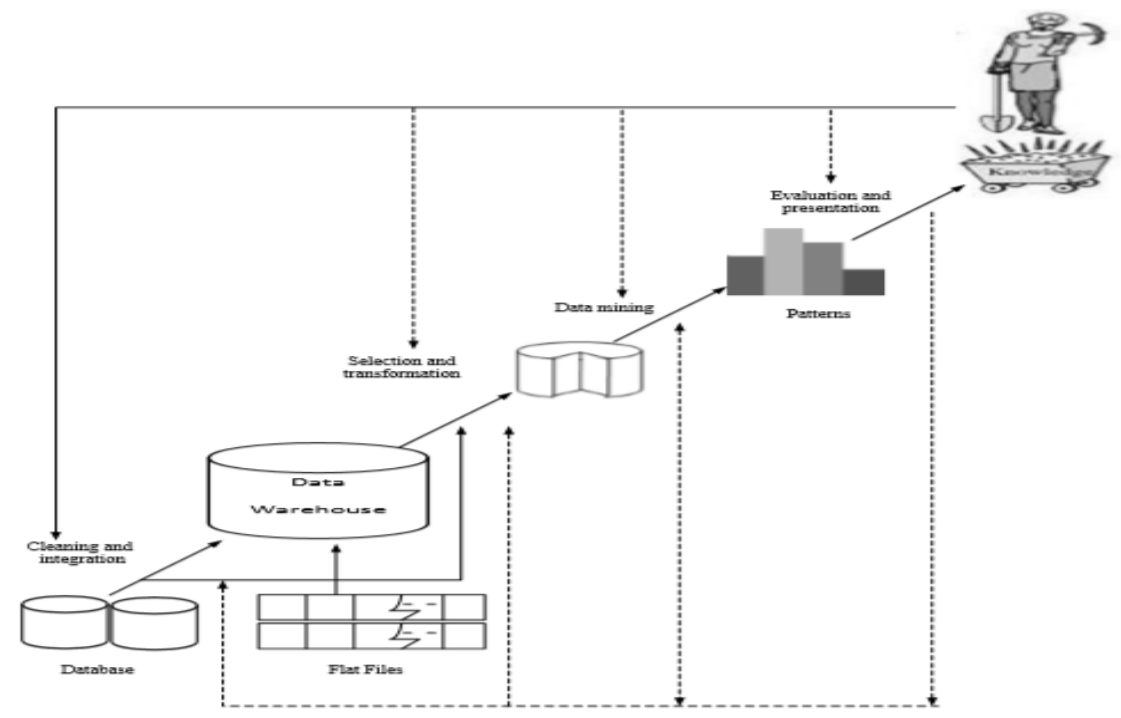

Gambar 1.1 Tahap-tahap Data Mining

1. Data Selection

Pemilihan (seleksi) sebuah data di dalam sekumpulan data operasional adalah tahap penggalian informasi KDD sebelum dimulai. Proses data mining menggunakan data hasil seleksi yang nantinya akan disimpan ke dalam suatu berkas, terpisah dari basis data operasional.

2. Pre-processing / Cleaning

Sebelum terjadinya proses data mining diperlukannya proses pembersihan pada data yang akan menjadi fokus KDD. Proses pembersihan data mencakup hal-hal seperti membuang duplikasi data, memeriksa data yang inkonsisten dan memperbaiki kesalahan pada data, seperti kesalahan cetak.

3. Transformation Coding

Merupakan proses transformasi pada data yang sudah terpilih, yang nantinya data tersebut sudah sesuai untuk proses data mining. Proses coding di dalam KDD adalah suatu proses yang mempunyai karakteristik dan tergantung pada jenis atau pola informasi yang akan dicari dalam basis data.

4. Data mining

Data mining merupakan sebuah proses mencari suatu pola atau sebuah informasi yang menarik dalam data yang terpilih dengan menggunakan teknik atau metode tertentu. Sebuah teknik, metode ataupun algoritma dalam data mining sangatlah bervariasi sehingga dalam pemilihan algoritma atau metode 
yang tepat tergantung pada tujuan dan proses KDD secara keseluruhan.

5. Interpretation / Evaluation

Proses dari data mining menghasilkan sebuah pola informasi dan penampilan pola tersebut harus dalam bentuk yang mudah untuk dimengerti oleh pihak yang berkepentingan. Tahap ini merupakan tahap terakhir dari KDD, tujuan dari tahap ini adalah untuk memastikan apakah pola atau informasi yang telah ditemukan bertentangan dengan fakta atau hipotesis yang ada sebelumnnya.

\subsection{Clustering}

Makna lain yang mengenai clustering adalah sebuah mekanisme klasifikasi dan banyak digunakan untuk dirancang dalam mengkategorikan data juga dipaparkan oleh [6]. Penggunaan teknik seperti ini sering digunakan dalam mode eksplorasi data, dan clustering dapat dilakukan dengan menggunakan berbagai algoritma yang berbeda salah satunya adalah $K$-Means.

\subsection{Algoritma Metode $\boldsymbol{K}$-Means}

K-Means adalah sebuah metode dalam clustering yang memiliki sifat non hierarki dan berusaha mempartisi data yang ada ke dalam bentuk satu atau lebih cluster dalam arti lain kelompok sehingga data yang memiliki karakteristik yang sama akan dikelompokkan kedalam cluster yang sama dan data yang berbeda dikelompokkan ke cluster yg lainnya [3]. Oleh karena itu, berikut ini merupakan cara kerja dari algoritma K-Means:

1. Menentukan $k$ sebagai jumlah cluster yang ingin dibentuk.

2. Kemudian membangkitkan $k$ centroid (titik pusat cluster) awal secara random.

3. Menghitung jarak dari setiap data ke masing-masing centroid. Pada tahap ini perlu dihitung antara jarak tiap data ke setiap pusat cluster. Jarak antara satu data dengan satu cluster tertentu nantinya akan menentukan sebuah data yang masuk kedalam cluster mana. Oleh karena itu, untuk menghitung antara jarak ke semua data ke setiap titik pusat cluster dapat menggunakan teori jarak Euclidian yang dirumuskan sebagai berikut :

$$
D(i, j)=\sqrt{\left(X_{1 i}-X_{1 j}\right)^{2}+\left(X_{2 i}-X_{2 j}\right)^{2}+\cdots+\left(X_{k i}-X_{k j}\right)^{2}}
$$

Dimana :

$\mathrm{D}(i, j)=$ Jarak data ke $i$ ke pusat cluster $j$

$\mathrm{X}_{k i}=$ Data ke $i$ pada atribut data ke $k$

$\mathrm{X}_{k i}=$ Titik pusat ke $j$ pada atribut ke $k$

4. Lalu setiap data akan dilakukan pemilihan jarak centroid yang terdekat.

5. Dan tentukan posisi centroid yang baru dengan cara menghitung nilai rata-rata dari data yang terletak pada centroid yang sama.

6. Kemudian kembali ke langkah-3 jika pada posisi centroid yang baru dengan yang lama tidak sama dan begitu seterusnya.

\section{METODOLOGI PENELITIAN}

\subsection{Metode Penelitian}

Dalam melakukan suatu penelitian memerlukan langkah-langkah atau cara tertentu yang menjadi pedoman selama proses penelitian, agar hasil penelitian sesuai dengan tujuan yang telah ditetapkan. Berikut adalah metodologi dalam penelitian ini yaitu:

1. Teknik Pengumpulan Data (Data Collecting)

Adapun beberapa teknik yang digunakan dalam pengumpulan data dari penelitian yaitu :

a. Pengamatan (Observasi)

Observasi merupakan teknik pengumpulan data yang dilakukan dengan cara melakukan tinjauan langsung ke tempat study kasus dimana akan dilakukan penelitian.

b. Wawancara (Interview)

Teknik wawancara dilakukan untuk mendapatkan informasi tambahan tentang data dari pihak-pihak yang memiliki wewenang agar memperoleh data yang dibutuhkan untuk menunjang penelitian ini.

2. Studi Kepustakaan (Library Search)

Untuk mendapatkan hasil teori yang valid untuk dijadikan sebuah landasan dapat mempelajari beberapa buku referensi.

\subsection{Metode Perancangan Sistem}


Di dalam metode perancangan sistem khususnya mengenai software atau perangkat lunak kita dapat mengadopsi beberapa metode diantaranya algoritma waterfall. Yang dimulai dari menganalisis masalah, Desain sistem, Pembanngunan sistem, Uji coba, dan Implementasi sistem.

\subsection{Alogiritma Sistem}

Algoritma sistem merupakan penjelasan dari langkah-langkah penyelesaian masalah dalam perancangan sistem data mining dalam klusterisasi dalam menganalisis area atau daerah yang memiliki permintaan barang paling besar dengan menggunakan metode K-Means Clustering.

Analisis yang dilakukan pada PT Indomarco Prismtama Cab.Medan yang bergerak dalam bidang ritel waralaba terbesar di Indonesia, sehingga dalam pemenuhan stok kebutuhan toko harus memiliki berbagai aspek yang dapat menguntungkan. Salah satunya adalah untuk pemenuhan stok tambahan yang yang mempengaruhi dengan jumlah penjualan disetiap masing-masing daerah toko tersebut yang perlu diperhatikan. Hal ini dapat dibantu dengan analisa menggunakan sebuah ilmu pengetahuan yaitu berupa data mining.

Berikut merupakan tabel area dari masing-masing regional IV PT Indomarco Prismatama Cab.Medan sempel yang diambil dari perusahaan dengan sampel produk rokok sebagai perhitungan pada metode.

Tabel 1.1 Data Permintaan Produk Rokok Setiap Kabupaten

\begin{tabular}{|c|c|c|c|}
\hline No & Area & Jlh Toko & Jlh Item \\
\hline 1 & Aceh & 2 & 15 \\
\hline 2 & Aceh Barat & 8 & 45 \\
\hline 3 & Aceh Besar & 7 & 41 \\
\hline 4 & Aceh Jaya & 1 & 11 \\
\hline 5 & Aceh Selatan & 4 & 38 \\
\hline 6 & Aceh Singkil & 1 & 8 \\
\hline 7 & Aceh Tamiang & 12 & 48 \\
\hline 8 & Aceh Tengah & 4 & 13 \\
\hline 9 & Aceh Tenggara & 8 & 42 \\
\hline 10 & Aceh Utara & 4 & 10 \\
\hline 11 & Asahan & 21 & 54 \\
\hline 12 & Banda Aceh & 22 & 14 \\
\hline 13 & Batu Bara & 12 & 41 \\
\hline 14 & Belawan & 1 & 10 \\
\hline 15 & Bener Meriah & 2 & 5 \\
\hline 16 & Binjai & 14 & 48 \\
\hline 17 & Bireuen & 7 & 24 \\
\hline 18 & Dairi & 11 & 49 \\
\hline 19 & Deli Serdang & 131 & 84 \\
\hline 20 & Gayo Lues & 1 & 17 \\
\hline 21 & Humbang Hasundutan & 2 & 24 \\
\hline 22 & Karo & 34 & 66 \\
\hline 23 & Kota Medan & 250 & 85 \\
\hline 24 & Labuhan Batu & 2 & 15 \\
\hline 25 & Labuhan Batu Utara & 9 & 33 \\
\hline 26 & Langkat & 25 & 60 \\
\hline 27 & Langsa & 4 & 26 \\
\hline 28 & Lhokseumawe & 1 & 12 \\
\hline 29 & Nagan Raya & 4 & 20 \\
\hline 30 & Pakpak Barat & 1 & 18 \\
\hline 31 & Pidie & 3 & 19 \\
\hline 32 & Pidie Jaya & 3 & 6 \\
\hline 33 & Samosir & 6 & 52 \\
\hline
\end{tabular}




\begin{tabular}{|c|c|c|c|}
\hline 34 & Serdang Bedagai & 51 & 24 \\
\hline 35 & Siantar & 23 & 76 \\
\hline 36 & Sibolga & 5 & 39 \\
\hline 37 & Sigli & 1 & 7 \\
\hline 38 & Simalungun & 28 & 54 \\
\hline 39 & Subulussalam & 4 & 20 \\
\hline 40 & Tanjung Balai & 15 & 10 \\
\hline
\end{tabular}

Dalam proses pengelompokan data kategori permintaan barang menggunakan 2 kriteria sebagai berikut :

Tabel 1.2 Kriteria

\begin{tabular}{|c|c|}
\hline Kode Kriteria & Kriteria \\
\hline K1 & Jumlah Toko \\
\hline K2 & Jumlah Item \\
\hline
\end{tabular}

Dan kemudian dilakukan penyelesaian masalah dengan mengadopsi metode

Sesuai dengan referensi yang telah dipaparkan pada bab sebelumnya, berikut ini adalah langkahlangkah penyelesaiannya yaitu:

1. Iterasi ke - 1

a. Penentuan pusat (centroid) awal cluster

Untuk menentukan pusat (centroid) awal ditentukan dengan acak (random) dari data yang sudah ada. Pada kasus ini pusat centroid awal adalah data Aceh, Batu Bara, dan Tanjung Balai.

Tabel 1.3 Titik Pusat (Centroid) Awal Cluster

\begin{tabular}{|c|c|c|c|}
\hline Centroid & Data & K1 & K2 \\
\hline Centroid 1 & Aceh & 2 & 15 \\
\hline Centroid 2 & Batu Bara & 12 & 41 \\
\hline Centroid 3 & Tanjung Balai & 15 & 10 \\
\hline
\end{tabular}

b.Perhitungan jarak dengan pusat cluster

Perhitungan jarak dari data area ke-1 terhadap titik pusat cluster adalah:

$\mathrm{D}(1,1)=\sqrt{(2-2)^{2}+(15-15)^{2}}=0,00$

$\mathrm{D}(1,2)=\sqrt{(2-12)^{2}+(15-41)^{2}}=27,86$

$\mathrm{D}(1,3)=\sqrt{(2-15)^{2}+(15-10)^{2}}=13,93$

Dan seterusnya dilakukan perhitungan jarak untuk data kategori area ke-2 sampai dengan data ke-40 kemudian akan didapatkan hasil perhitungan jarak setiap data terhadap pusat cluster baru sebagai berikut

Tabel 1.4 Hasil Perhitungan pada Iterasi ke-1

\begin{tabular}{|l|c|c|c|c|c|c|}
\hline \multicolumn{1}{|c|}{ Area } & $\mathbf{C 1}$ & $\mathbf{C 2}$ & $\mathbf{C 3}$ & $\begin{array}{c}\text { Jarak } \\
\text { Terpendek }\end{array}$ & Cluster & $\begin{array}{c}\text { Jarak } \\
\text { Terpendek } \\
\text { ^2 }\end{array}$ \\
\hline Aceh & 0,00 & 27,86 & 13,93 & 0,00 & $\mathrm{C} 1$ & 0,00 \\
\hline Aceh Barat & 30,59 & 5,66 & 35,69 & 5,66 & $\mathrm{C} 2$ & 32,00 \\
\hline Aceh Besar & 26,48 & 5,00 & 32,02 & 5,00 & $\mathrm{C} 2$ & 25,00 \\
\hline Aceh Jaya & 4,12 & 31,95 & 14,04 & 4,12 & $\mathrm{C} 1$ & 17,00 \\
\hline Aceh Selatan & 23,09 & 8,54 & 30,08 & 8,54 & $\mathrm{C} 2$ & 73,00 \\
\hline Aceh Singkil & 7,07 & 34,79 & 14,14 & 7,07 & $\mathrm{C} 1$ & 50,00 \\
\hline Aceh Tamiang & 34,48 & 7,00 & 38,12 & 7,00 & $\mathrm{C} 2$ & 49,00 \\
\hline Aceh Tengah & 2,83 & 29,12 & 11,40 & 2,83 & $\mathrm{C} 1$ & 8,00 \\
\hline Aceh Tenggara & 27,66 & 4,12 & 32,76 & 4,12 & $\mathrm{C} 2$ & 17,00 \\
\hline Aceh Utara & 5,39 & 32,02 & 11,00 & 5,39 & $\mathrm{C} 1$ & 29,00 \\
\hline Asahan & 43,38 & 15,81 & 44,41 & 15,81 & $\mathrm{C} 2$ & 250,00 \\
\hline Banda Aceh & 20,02 & 28,79 & 8,06 & 8,06 & $\mathrm{C} 3$ & 65,00 \\
\hline Belawan & 5,10 & 32,89 & 14,00 & 5,10 & $\mathrm{C} 1$ & 26,00 \\
\hline Bener Meriah & 10,00 & 37,36 & 13,93 & 10,00 & $\mathrm{C} 1$ & 100,00 \\
\hline
\end{tabular}




\begin{tabular}{|l|c|c|c|c|c|c|}
\hline Binjai & 35,11 & 7,28 & 38,01 & 7,28 & $\mathrm{C} 2$ & 53,00 \\
\hline Bireuen & 10,30 & 17,72 & 16,12 & 10,30 & $\mathrm{C} 1$ & 106,00 \\
\hline Dairi & 35,17 & 8,06 & 39,20 & 8,06 & $\mathrm{C} 2$ & 65,00 \\
\hline Deli Serdang & 146,29 & 126,53 & 137,59 & 126,53 & $\mathrm{C} 2$ & $16.010,00$ \\
\hline Gayo Lues & 2,24 & 26,40 & 15,65 & 2,24 & $\mathrm{C} 1$ & 5,00 \\
\hline Humbang Hasundutan & 9,00 & 19,72 & 19,10 & 9,00 & $\mathrm{C} 1$ & 81,00 \\
\hline Karo & 60,21 & 33,30 & 59,14 & 33,30 & $\mathrm{C} 2$ & $1.109,00$ \\
\hline Kota Medan & 257,69 & 242,03 & 246,68 & 242,03 & $\mathrm{C} 2$ & $58.580,00$ \\
\hline Labuhan Batu & 0,00 & 27,86 & 13,93 & 0,00 & $\mathrm{C} 1$ & 0,00 \\
\hline Labuhan Batu Utara & 19,31 & 8,54 & 23,77 & 8,54 & $\mathrm{C} 2$ & 73,00 \\
\hline Langkat & 50,54 & 23,02 & 50,99 & 23,02 & $\mathrm{C} 2$ & 530,00 \\
\hline Langsa & 11,18 & 17,00 & 19,42 & 11,18 & $\mathrm{C} 1$ & 125,00 \\
\hline Lhokseumawe & 3,16 & 31,02 & 14,14 & 3,16 & $\mathrm{C} 1$ & 10,00 \\
\hline Nagan Raya & 5,39 & 22,47 & 14,87 & 5,39 & $\mathrm{C} 1$ & 29,00 \\
\hline Pakpak Barat & 3,16 & 25,50 & 16,12 & 3,16 & $\mathrm{C} 1$ & 10,00 \\
\hline
\end{tabular}

Tabel 1.4 Hasil Perhitungan pada Iterasi ke-1 (Lanjutan)

\begin{tabular}{|l|c|c|c|c|c|c|}
\hline \multicolumn{1}{|c|}{ Area } & C1 & C2 & C3 & $\begin{array}{c}\text { Jarak } \\
\text { Terpendek }\end{array}$ & Cluster & $\begin{array}{c}\text { Jarak } \\
\text { Terpendek } \\
\text { ^2 }\end{array}$ \\
\hline Pidie & 4,12 & 23,77 & 15,00 & 4,12 & $\mathrm{C} 1$ & 17,00 \\
\hline Pidie Jaya & 9,06 & 36,14 & 12,65 & 9,06 & $\mathrm{C} 1$ & 82,00 \\
\hline Samosir & 37,22 & 12,53 & 42,95 & 12,53 & $\mathrm{C} 2$ & 157,00 \\
\hline Serdang Bedagai & 49,82 & 42,54 & 38,63 & 38,63 & $\mathrm{C} 3$ & $1.492,00$ \\
\hline Siantar & 64,51 & 36,69 & 66,48 & 36,69 & $\mathrm{C} 2$ & $1.346,00$ \\
\hline Sibolga & 24,19 & 7,28 & 30,68 & 7,28 & $\mathrm{C} 2$ & 53,00 \\
\hline Sigli & 8,06 & 35,74 & 14,32 & 8,06 & $\mathrm{C} 1$ & 65,00 \\
\hline Simalungun & 46,87 & 20,62 & 45,88 & 20,62 & $\mathrm{C} 2$ & 425,00 \\
\hline Subulussalam & 5,39 & 22,47 & 14,87 & 5,39 & $\mathrm{C} 1$ & 29,00 \\
\hline Tanjung Balai & 13,93 & 31,14 & 0,00 & 0,00 & $\mathrm{C} 3$ & 0,00 \\
\hline
\end{tabular}

a. Menghitung Besar Rasio

Rasio besaran antara BCV (Between Cluster Variation) dengan WCV (Within Cluster Variation) :

Karena centroid m1 $(2 ; 15), \mathrm{m} 2(12 ; 41), \mathrm{m} 3(15 ; 10)$

$d(m 1, m 2)=\sqrt{(2-12)^{2}+(15-41)^{2}}=27,587$

$d(m 1, m 3)=\sqrt{(2-15)^{2}+(15-10)^{2}}=13,928$

$d(m 2, m 3)=\sqrt{(12-15)^{2}+(41-10)^{2}}=31,145$

$\mathrm{BCV}=\mathrm{d}(\mathrm{m} 1, \mathrm{~m} 2)+\mathrm{d}(\mathrm{m} 1, \mathrm{~m} 3)+\mathrm{d}(\mathrm{m} 2, \mathrm{~m} 3)$

$=27,587+13,928+31,145$

$=72,930$

Besar Rasio $=72,930 / 81.193,00=0,001$

Karena perhitungan masih perhitungan pada iterasi 1 maka lanjutkan ke iterasi 2.

b. Perhitungan pusat cluster baru

Untuk mendapatkan pusat cluster yang baru diperlukan untuk mengelompokkan data berdasarkan jarak terdekat dengan pusat cluster. Kemudian pusat cluster baru dihitung berdasarkan data anggota tiap-tiap cluster dan membagikan dengan jumlah anggota masing-masing cluster.

\begin{tabular}{|c|c|c|c|}
\hline C1 & & & \\
\hline Area & K1 & K2 & Cluster \\
\hline Aceh & 2 & 15 & $\mathrm{C} 1$ \\
\hline Aceh Jaya & 1 & 11 & $\mathrm{C} 1$ \\
\hline Aceh Singkil & 1 & 8 & $\mathrm{C} 1$ \\
\hline Aceh Tengah & 4 & 13 & $\mathrm{C} 1$ \\
\hline
\end{tabular}




\begin{tabular}{|l|c|c|c|}
\hline Aceh Utara & 4 & 10 & $\mathrm{C} 1$ \\
\hline Belawan & 1 & 10 & $\mathrm{C} 1$ \\
\hline Bener Meriah & 2 & 5 & $\mathrm{C} 1$ \\
\hline Bireuen & 7 & 24 & $\mathrm{C} 1$ \\
\hline Gayo Lues & 1 & 17 & $\mathrm{C} 1$ \\
\hline Humbang Hasundutan & 2 & 24 & $\mathrm{C} 1$ \\
\hline Labuhan Batu & 2 & 15 & $\mathrm{C} 1$ \\
\hline Langsa & 4 & 26 & $\mathrm{C} 1$ \\
\hline Lhokseumawe & 1 & 12 & $\mathrm{C} 1$ \\
\hline Nagan Raya & 4 & 20 & $\mathrm{C} 1$ \\
\hline Pakpak Barat & 1 & 18 & $\mathrm{C} 1$ \\
\hline Pidie & 3 & 19 & $\mathrm{C} 1$ \\
\hline Pidie Jaya & 3 & 6 & $\mathrm{C} 1$ \\
\hline Sigli & 1 & 7 & $\mathrm{C} 1$ \\
\hline Subulussalam & 4 & 20 & $\mathrm{C} 1$ \\
\hline \multicolumn{1}{|c|}{ Mean C1 } & $\mathbf{2 , 5 3}$ & $\mathbf{1 4 , 7 4}$ & $\mathbf{1 9}$ \\
\hline
\end{tabular}

Tabel 1.6 Kelompok Cluster 2

\begin{tabular}{|c|c|c|c|}
\hline C2 & \multicolumn{3}{|l|}{} \\
\hline Area & K1 & K2 & Cluster \\
\hline Aceh Barat & 8 & 45 & C2 \\
\hline
\end{tabular}

Tabel 1.6 Kelompok Cluster 2 (Lanjutan)

\begin{tabular}{|c|c|c|c|}
\hline C2 & & & \\
\hline Area & K1 & K2 & Cluster \\
\hline Aceh Besar & 7 & 41 & $\mathrm{C} 2$ \\
\hline Aceh Selatan & 4 & 38 & $\mathrm{C} 2$ \\
\hline Aceh Tamiang & 12 & 48 & $\mathrm{C} 2$ \\
\hline Aceh Tenggara & 8 & 42 & $\mathrm{C} 2$ \\
\hline Asahan & 21 & 54 & $\mathrm{C} 2$ \\
\hline Batu Bara & 12 & 41 & $\mathrm{C} 2$ \\
\hline Binjai & 14 & 48 & $\mathrm{C} 2$ \\
\hline Dairi & 11 & 49 & $\mathrm{C} 2$ \\
\hline Deli Serdang & 131 & 84 & $\mathrm{C} 2$ \\
\hline Karo & 34 & 66 & $\mathrm{C} 2$ \\
\hline Kota Medan & 250 & 85 & $\mathrm{C} 2$ \\
\hline Labuhan Batu Utara & 9 & 33 & $\mathrm{C} 2$ \\
\hline Langkat & 25 & 60 & $\mathrm{C} 2$ \\
\hline Samosir & 6 & 52 & $\mathrm{C} 2$ \\
\hline Siantar & 23 & 76 & $\mathrm{C} 2$ \\
\hline Sibolga & 5 & 39 & $\mathrm{C} 2$ \\
\hline Simalungun & 28 & 54 & $\mathrm{C} 2$ \\
\hline Mean C2 & 33,78 & 53,06 & 18 \\
\hline
\end{tabular}

Tabel 1.7 Kelompok Cluster 3

\begin{tabular}{|c|c|c|c|}
\hline C3 & \multicolumn{3}{|l}{} \\
\hline Area & K1 & K2 & Cluster \\
\hline
\end{tabular}




\begin{tabular}{|l|c|c|c|} 
Banda Aceh & 22 & 14 & C3 \\
\hline Serdang Bedagai & 51 & 24 & C3 \\
\hline Tanjung Balai & 15 & 10 & C3 \\
\hline Mean C3 & $\mathbf{2 9 , 3 3}$ & $\mathbf{1 6 , 0 0}$ & $\mathbf{3}$ \\
\hline
\end{tabular}

Dari hasil tabel cluster tersebut maka diperoleh centroid baru yaitu :

$\mathrm{m} 1=(2,53 ; 14,74)$

$\mathrm{m} 2=(33,78 ; 53,06)$

$\mathrm{m} 3=(29,33 ; 16,00)$

Tabel 1.8 Pusat (centroid) cluster baru

\begin{tabular}{|c|c|c|}
\hline Centroid & K1 & K2 \\
\hline Centroid 1 & 2,53 & 14,74 \\
\hline Centroid 2 & 33,78 & 53,06 \\
\hline Centroid 3 & 29,33 & 16,00 \\
\hline
\end{tabular}

2. Iterasi ke -2

a. Perhitungan jarak dengan pusat cluster

Perhitungan jarak dari data pelanggan ke-1 terhadap titik pusat cluster adalah:

$\mathrm{D}(1,1)=\sqrt{(2-2,53)^{2}+(15-14,74)^{2}}=0,59$

$\mathrm{D}(1,2)=\sqrt{(2-33,78)^{2}+(15-53,06)^{2}}=49,58$

$\mathrm{D}(1,3)=\sqrt{(2-29,33)^{2}+(15-16,00)^{2}}=27,35$

Dan seterusnya dilakukan perhitungan jarak untuk data kategori area ke-2 sampai data ke-40 kemudian akan didapatkan hasil perhitungan jarak setiap data terhadap pusat cluster baru sebagai berikut :

Tabel 1.9 Hasil Perhitungan pada iterasi ke-2

\begin{tabular}{|l|c|c|c|c|c|c|}
\hline \multicolumn{1}{|c|}{ Area } & C1 & $\mathbf{C 2}$ & $\mathbf{C 3}$ & $\begin{array}{c}\text { Jarak } \\
\text { Terpendek }\end{array}$ & Cluster & $\begin{array}{c}\text { Jarak } \\
\text { Terpendek } \\
\text { ^2 }\end{array}$ \\
\hline Aceh & 0,59 & 49,58 & 27,35 & 0,59 & $\mathrm{C} 1$ & 0,35 \\
\hline Aceh Barat & 30,75 & 27,01 & 36,00 & 27,01 & $\mathrm{C} 2$ & 729,39 \\
\hline Aceh Besar & 26,64 & 29,37 & 33,52 & 26,64 & $\mathrm{C} 1$ & 709,77 \\
\hline Aceh Jaya & 4,04 & 53,32 & 28,77 & 4,04 & $\mathrm{C} 1$ & 16,29 \\
\hline Aceh Selatan & 23,31 & 33,37 & 33,55 & 23,31 & $\mathrm{C} 1$ & 543,35 \\
\hline Aceh Singkil & 6,91 & 55,72 & 29,44 & 6,91 & $\mathrm{C} 1$ & 47,71 \\
\hline Aceh Tamiang & 34,59 & 22,36 & 36,39 & 22,36 & $\mathrm{C} 2$ & 499,83 \\
\hline Aceh Tengah & 2,28 & 49,91 & 25,51 & 2,28 & $\mathrm{C} 1$ & 5,19 \\
\hline Aceh Tenggara & 27,81 & 28,05 & 33,63 & 27,81 & $\mathrm{C} 1$ & 773,24 \\
\hline Aceh Utara & 4,96 & 52,35 & 26,03 & 4,96 & $\mathrm{C} 1$ & 24,61 \\
\hline Asahan & 43,39 & 12,81 & 38,90 & 12,81 & $\mathrm{C} 2$ & 164,16 \\
\hline Banda Aceh & 19,49 & 40,79 & 7,60 & 7,60 & $\mathrm{C} 3$ & 57,78 \\
\hline Batu Bara & 27,92 & 24,89 & 30,42 & 24,89 & $\mathrm{C} 2$ & 619,61 \\
\hline Belawan & 4,98 & 54,11 & 28,96 & 4,98 & $\mathrm{C} 1$ & 24,77 \\
\hline Bener Meriah & 9,75 & 57,61 & 29,46 & 9,75 & $\mathrm{C} 1$ & 95,08 \\
\hline Binjai & 35,19 & 20,41 & 35,48 & 20,41 & $\mathrm{C} 2$ & 416,72 \\
\hline Bireuen & 10,29 & 39,51 & 23,72 & 10,29 & $\mathrm{C} 1$ & 105,82 \\
\hline Dairi & 35,30 & 23,14 & 37,75 & 23,14 & $\mathrm{C} 2$ & 535,27 \\
\hline Deli Serdang & 145,96 & 102,03 & 122,31 & 102,03 & $\mathrm{C} 2$ & $10.409,72$ \\
\hline Gayo Lues & 2,73 & 48,73 & 28,35 & 2,73 & $\mathrm{C} 1$ & 7,45 \\
\hline Humbang Hasundutan & 9,28 & 43,06 & 28,48 & 9,28 & $\mathrm{C} 1$ & 86,08 \\
\hline Karo & 60,15 & 12,95 & 50,22 & 12,95 & $\mathrm{C} 2$ & 167,61 \\
\hline Kota Medan & 257,26 & 218,57 & 231,20 & 218,57 & $\mathrm{C} 2$ & $47.772,50$ \\
\hline Labuhan Batu & 0,59 & 49,58 & 27,35 & 0,59 & $\mathrm{C} 1$ & 0,35 \\
\hline Labuhan Batu Utara & 19,38 & 31,88 & 26,50 & 19,38 & $\mathrm{C} 1$ & 375,45 \\
\hline
\end{tabular}




\begin{tabular}{|l|c|c|c|c|c|c|}
\hline Langkat & 50,54 & 11,19 & 44,21 & 11,19 & $\mathrm{C} 2$ & 125,27 \\
\hline Langsa & 11,36 & 40,23 & 27,24 & 11,36 & $\mathrm{C} 1$ & 129,03 \\
\hline Lhokseumawe & 3,13 & 52,54 & 28,61 & 3,13 & $\mathrm{C} 1$ & 9,82 \\
\hline Nagan Raya & 5,47 & 44,49 & 25,65 & 5,47 & $\mathrm{C} 1$ & 29,87 \\
\hline Pakpak Barat & 3,60 & 47,99 & 28,40 & 3,60 & $\mathrm{C} 1$ & 12,98 \\
\hline Pidie & 4,29 & 45,90 & 26,50 & 4,29 & $\mathrm{C} 1$ & 18,40 \\
\hline Pidie Jaya & 8,75 & 56,23 & 28,17 & 8,75 & $\mathrm{C} 1$ & 76,56 \\
\hline Samosir & 37,42 & 27,80 & 42,90 & 27,80 & $\mathrm{C} 2$ & 772,72 \\
\hline Serdang Bedagai & 49,35 & 33,78 & 23,10 & 23,10 & $\mathrm{C} 3$ & 533,44 \\
\hline Siantar & 64,59 & 25,35 & 60,33 & 25,35 & $\mathrm{C} 2$ & 642,61 \\
\hline Sibolga & 24,39 & 32,03 & 33,48 & 24,39 & $\mathrm{C} 1$ & 594,82 \\
\hline Sigli & 7,89 & 56,53 & 29,73 & 7,89 & $\mathrm{C} 1$ & 62,19 \\
\hline Simalungun & 46,80 & 5,85 & 38,02 & 5,85 & $\mathrm{C} 2$ & 34,27 \\
\hline Subulussalam & 5,47 & 44,49 & 25,65 & 5,47 & $\mathrm{C} 1$ & 29,87 \\
\hline Tanjung Balai & 13,34 & 46,97 & 15,54 & 13,34 & $\mathrm{C} 1$ & 178,03 \\
\hline
\end{tabular}

b. Menghitung Besar Rasio

Rasio besaran antara BCV (Between Cluster Variation) dengan WCV (Within Cluster Variation) :

Karena centroidnya adalah sebagai berikut :

$\mathrm{m} 1=(2,53 ; 14,74)$

$\mathrm{m} 2=(33,78 ; 53,06)$

$\mathrm{m} 3=(29,33 ; 16,00)$

$d(m 1, m 2)=\sqrt{(2,53-33,78)^{2}+(14,74-53,06)^{2}}=49,447$

$d(m 1, m 3)=\sqrt{(2,53-29,33)^{2}+(14,74-16,00)^{2}}=26,837$

$d(m 2, m 3)=\sqrt{(33,78-29,33)^{2}+(53,06-16,00)^{2}}=37,321$

$\mathrm{BCV}=\mathrm{d}(\mathrm{m} 1, \mathrm{~m} 2)+\mathrm{d}(\mathrm{m} 1, \mathrm{~m} 3)+\mathrm{d}(\mathrm{m} 2, \mathrm{~m} 3)$

$=49,447+26,837+37,321=113,605$

Besar Rasio $=113,605 / 67.437,98=0,002$

Karena rasio yang baru lebih besar dari rasio sebelumnya maka diperlukan untuk melanjutkan perhitungan ke iterasi selanjutnya.

c. Perhitungan pusat cluster baru

Untuk mendapatkan pusat cluster yang baru diperlukan untuk klusterisasi data berdasarkan jarak terdekat dengan pusat cluster. Kemudian pusat cluster baru dihitung berdasarkan data anggota tiaptiap cluster dan membagikan dengan jumlah anggota masing-masing cluster.

Tabel 10 Kelompok Cluster 1

\begin{tabular}{|c|c|c|c|}
\hline C1 & & & \\
\hline Area & K1 & K2 & Cluster \\
\hline Aceh & 2 & 15 & $\mathrm{C} 1$ \\
\hline Aceh Besar & 7 & 41 & $\mathrm{C} 1$ \\
\hline Aceh Jaya & 1 & 11 & $\mathrm{C} 1$ \\
\hline Aceh Selatan & 4 & 38 & $\mathrm{C} 1$ \\
\hline Aceh Singkil & 1 & 8 & $\mathrm{C} 1$ \\
\hline Aceh Tengah & 4 & 13 & $\mathrm{C} 1$ \\
\hline Aceh Tenggara & 8 & 42 & $\mathrm{C} 1$ \\
\hline Aceh Utara & 4 & 10 & $\mathrm{C} 1$ \\
\hline Belawan & 1 & 10 & $\mathrm{C} 1$ \\
\hline Bener Meriah & 2 & 5 & $\mathrm{C} 1$ \\
\hline Bireuen & 7 & 24 & $\mathrm{C} 1$ \\
\hline Gayo Lues & 1 & 17 & $\mathrm{C} 1$ \\
\hline Humbang Hasundutan & 2 & 24 & $\mathrm{C} 1$ \\
\hline Labuhan Batu & 2 & 15 & $\mathrm{C} 1$ \\
\hline Labuhan Batu Utara & 9 & 33 & $\mathrm{C} 1$ \\
\hline Langsa & 4 & 26 & $\mathrm{C} 1$ \\
\hline
\end{tabular}




\begin{tabular}{|c|c|c|c|}
\hline Lhokseumawe & 1 & 12 & $\mathrm{C} 1$ \\
\hline Nagan Raya & 4 & 20 & $\mathrm{C} 1$ \\
\hline Pakpak Barat & 1 & 18 & $\mathrm{C} 1$ \\
\hline Pidie & 3 & 19 & $\mathrm{C} 1$ \\
\hline Pidie Jaya & 3 & 6 & $\mathrm{C} 1$ \\
\hline Sibolga & 5 & 39 & $\mathrm{C} 1$ \\
\hline Sigli & 1 & 7 & $\mathrm{C} 1$ \\
\hline Subulussalam & 4 & 20 & $\mathrm{C} 1$ \\
\hline Tanjung Balai & 15 & 10 & $\mathrm{C} 1$ \\
\hline Mean C1 & 3,84 & 19,32 & 25 \\
\hline
\end{tabular}

Tabel 1.11 Kelompok Cluster 2

\begin{tabular}{|l|c|c|c|}
\hline \multicolumn{1}{|c|}{ C2 } & \multicolumn{5}{c|}{} \\
\hline Area & K1 & K2 & Cluster \\
\hline Aceh Barat & 8 & 45 & C2 \\
\hline Aceh Tamiang & 12 & 48 & C2 \\
\hline Asahan & 21 & 54 & C2 \\
\hline Batu Bara & 12 & 41 & C2 \\
\hline Binjai & 14 & 48 & C2 \\
\hline Dairi & 11 & 49 & C2 \\
\hline Deli Serdang & 131 & 84 & $\mathrm{C} 2$ \\
\hline Karo & 34 & 66 & $\mathrm{C} 2$ \\
\hline Kota Medan & 250 & 85 & $\mathrm{C} 2$ \\
\hline Langkat & 25 & 60 & $\mathrm{C} 2$ \\
\hline Samosir & 6 & 52 & $\mathrm{C} 2$ \\
\hline
\end{tabular}

Tabel 1.12 Kelompok Cluster 2 (Lanjutan)

\begin{tabular}{|c|c|c|c|}
\hline \multicolumn{1}{|c|}{ C2 } & \multicolumn{3}{|c|}{} \\
\hline Area & K1 & K2 & Cluster \\
\hline Siantar & 23 & 76 & C2 \\
\hline Simalungun & 28 & 54 & C2 \\
\hline Mean C2 & $\mathbf{4 4 , 2 3}$ & $\mathbf{5 8 , 6 2}$ & $\mathbf{1 3}$ \\
\hline
\end{tabular}

Tabel 1.12 Kelompok Cluster 3

\begin{tabular}{|c|c|c|c|}
\hline C3 & \multicolumn{5}{|c|}{} \\
\hline Area & K1 & K2 & Cluster \\
\hline Banda Aceh & 22 & 14 & C3 \\
\hline Serdang Bedagai & 51 & 24 & C3 \\
\hline Mean C3 & $\mathbf{3 6 , 5 0}$ & $\mathbf{1 9 , 0 0}$ & $\mathbf{2}$ \\
\hline
\end{tabular}

Dari tabel diatas diperoleh centroid baru yaitu :

$\mathrm{m} 1=(3,84 ; 19,32)$

$\mathrm{m} 2=(44,32 ; 58,62)$

$\mathrm{m} 3=(36,50,19,00)$

Tabel 1.13 Pusat (centroid) cluster baru

\begin{tabular}{|c|c|c|}
\hline Centroid & K1 & K2 \\
\hline Centroid 1 & 3,84 & 19,32 \\
\hline Centroid 2 & 44,23 & 58,62 \\
\hline
\end{tabular}


3. Iterasi ke -3

Centroid 3

36,50

19,00

a. Perhitungan jarak dengan pusat cluster

Perhitungan jarak dari data area ke-1 terhadap titik pusat cluster adalah sebagai berikut :

$\mathrm{D}(1,1)=\sqrt{(2-3,84)^{2}+(15-19,32)^{2}}=4,70$

$\mathrm{D}(1,2)=\sqrt{(2-44,23)^{2}+(15-58,62)^{2}}=60,71$

$\mathrm{D}(1,3)=\sqrt{\left(2-36,50^{2}+(15-19,00)^{2}\right.}=34,73$

Dan seterusnya dilakukan perhitungan jarak untuk data kategori area ke-2

sampai dengan data area ke-40 kemudian akan didapatkan hasil perhitungan jarak setiap data terhadap pusat cluster baru sebagai berikut :

Tabel 1.14 Hasil Perhitungan pada iterasi ke-3

\begin{tabular}{|l|c|c|c|c|c|c|}
\hline \multicolumn{1}{|c|}{ Area } & C1 & C2 & C3 & $\begin{array}{c}\text { Jarak } \\
\text { Terpendek }\end{array}$ & Cluster & $\begin{array}{c}\text { Jarak } \\
\text { Terpendek } \\
\text { ^2 }\end{array}$ \\
\hline Aceh & 4,70 & 60,71 & 34,73 & 4,70 & C1 & 22,048 \\
\hline Aceh Barat & 26,01 & 38,70 & 38,58 & 26,01 & C1 & 676,768 \\
\hline Aceh Besar & 21,91 & 41,19 & 36,8 & 21,91 & C1 & 480,008 \\
\hline Aceh Jaya & 8,79 & 64,31 & 36,39 & 8,79 & C1 & 77,288 \\
\hline Aceh Selatan & 18,68 & 45,21 & 37,65 & 18,68 & C1 & 348,968 \\
\hline Aceh Singkil & 11,67 & 66,56 & 37,17 & 11,67 & C1 & 136,208 \\
\hline Aceh Tamiang & 29,82 & 33,93 & 37,96 & 29,82 & C1 & 889,128 \\
\hline Aceh Tengah & 6,32 & 60,82 & 33,05 & 6,32 & $\mathrm{C} 1$ & 39,968 \\
\hline Aceh Tenggara & 23,06 & 39,86 & 36,62 & 23,06 & $\mathrm{C} 1$ & 531,688 \\
\hline Aceh Utara & 9,32 & 63,10 & 33,72 & 9,32 & $\mathrm{C} 1$ & 86,888 \\
\hline Asahan & 38,69 & 23,68 & 38,28 & 23,68 & $\mathrm{C} 2$ & 560,97041 \\
\hline Banda Aceh & 18,92 & 49,85 & 15,34 & 15,34 & $\mathrm{C} 3$ & 235,25 \\
\hline Batu Bara & 23,16 & 36,73 & 32,93 & 23,16 & $\mathrm{C} 1$ & 536,608 \\
\hline Belawan & 9,74 & 65,06 & 36,62 & 9,74 & $\mathrm{C} 1$ & 94,928 \\
\hline Bener Meriah & 14,44 & 68,25 & 37,23 & 14,44 & $\mathrm{C} 1$ & 208,448 \\
\hline
\end{tabular}

Tabel 1.14 Hasil Perhitungan pada iterasi ke-3 (Lanjutan)

\begin{tabular}{|l|c|c|c|c|c|c|}
\hline \multicolumn{1}{|c}{ Area } & C1 & C2 & C3 & $\begin{array}{c}\text { Jarak } \\
\text { Terpendek }\end{array}$ & Cluster & $\begin{array}{c}\text { Jarak } \\
\text { Terpendek } \\
\text { ^2 }\end{array}$ \\
\hline Binjai & 30,43 & 32,04 & 36,7 & 30,43 & C1 & 925,768 \\
\hline Bireuen & 5,65 & 50,84 & 29,92 & 5,65 & $\mathrm{C} 1$ & 31,888 \\
\hline Dairi & 30,53 & 34,59 & 39,37 & 30,53 & $\mathrm{C} 1$ & 932,168 \\
\hline Deli Serdang & 142,66 & 90,41 & 114,7 & 90,41 & $\mathrm{C} 2$ & 8173,2781 \\
\hline Gayo Lues & 3,67 & 60,01 & 35,56 & 3,67 & $\mathrm{C} 1$ & 13,448 \\
\hline Humbang Hasundutan & 5,03 & 54,60 & 34,86 & 5,03 & $\mathrm{C} 1$ & 25,288 \\
\hline Karo & 55,58 & 12,62 & 47,07 & 12,62 & $\mathrm{C} 2$ & 159,20118 \\
\hline Kota Medan & 254,77 & 207,45 & 223,5 & 207,45 & $\mathrm{C} 2$ & 43037,124 \\
\hline Labuhan Batu & 4,70 & 60,71 & 34,73 & 4,70 & $\mathrm{C} 1$ & 22,048 \\
\hline Labuhan Batu Utara & 14,62 & 43,56 & 30,86 & 14,62 & $\mathrm{C} 1$ & 213,768 \\
\hline Langkat & 45,85 & 19,28 & 42,58 & 19,28 & $\mathrm{C} 2$ & 371,73964 \\
\hline Langsa & 6,68 & 51,79 & 33,25 & 6,68 & $\mathrm{C} 1$ & 44,648 \\
\hline Lhokseumawe & 7,85 & 63,58 & 36,18 & 7,85 & $\mathrm{C} 1$ & 61,648 \\
\hline Nagan Raya & 0,70 & 55,76 & 32,52 & 0,70 & $\mathrm{C} 1$ & 0,488 \\
\hline Pakpak Barat & 3,13 & 59,32 & 35,51 & 3,13 & $\mathrm{C} 1$ & 9,808 \\
\hline Pidie & 0,90 & 57,18 & 33,5 & 0,90 & $\mathrm{C} 1$ & 0,808 \\
\hline Pidie Jaya & 13,35 & 66,85 & 35,93 & 13,35 & $\mathrm{C} 1$ & 178,128 \\
\hline Samosir & 32,75 & 38,80 & 44,94 & 32,75 & $\mathrm{C} 1$ & 1072,648 \\
\hline Serdang Bedagai & 47,39 & 35,27 & 15,34 & 15,34 & $\mathrm{C} 3$ & 235,25 \\
\hline
\end{tabular}

Title of manuscript is short and clear, implies research results (First Author) 


\begin{tabular}{|l|c|c|c|c|c|c|}
\hline Siantar & 59,83 & 27,44 & 58,58 & 27,44 & C2 & 752,97041 \\
\hline Sibolga & 19,71 & 43,86 & 37,31 & 19,71 & C1 & 388,648 \\
\hline Sigli & 12,64 & 67,33 & 37,47 & 12,64 & C1 & 159,848 \\
\hline Simalungun & 42,27 & 16,87 & 36,02 & 16,87 & C2 & 284,73964 \\
\hline Subulussalam & 0,70 & 55,76 & 32,52 & 0,70 & C1 & 0,488 \\
\hline Tanjung Balai & 14,54 & 56,73 & 23,31 & 14,54 & C1 & 211,408 \\
\hline
\end{tabular}

b. Menghitung Besar Rasio

Rasio besaran antara BCV (Between Cluster Variation) dengan WCV

(Within Cluster Variation):

Karena centroidnya adalah sebagai berikut :

$\mathrm{m} 1=(3,84 ; 19,32)$

$\mathrm{m} 2=(44,32 ; 58,62)$

$\mathrm{m} 3=(36,50,19,00)$

$d(m 1, m 2)=\sqrt{(3,84-44,32)^{2}+(19,32-58,62)^{2}}=56,352$

$d(m 1, m 3)=\sqrt{(3,84-36,50)^{2}+(19,32-19,00)^{2}=32,662}$

$d(m 2, m 3)=\sqrt{(44,32-36,50)^{2}+(58,62-19,00)^{2}}=40,363$

$\mathrm{BCV}=\mathrm{d}(\mathrm{m} 1, \mathrm{~m} 2)+\mathrm{d}(\mathrm{m} 1, \mathrm{~m} 3)+\mathrm{d}(\mathrm{m} 2, \mathrm{~m} 3)$

$=56,352+32,662+40,363=129,376$

Besar Rasio $=129,376 / 62.232,41=0,002$

Karena rasio yang baru tidak lagi lebih besar dari rasio sebelumnya maka proses perhitungan iterasi dihentikan.

4. Kesimpulan

Karena iterasi telah mencapai akhir atau selesai maka dari perhitungan tersebut diperoleh kesimpulan sebagai berikut:

Tabel 1.15 Hasil Proses K-Means

\begin{tabular}{|l|l|l|l|}
\hline \multicolumn{1}{|c|}{ Area } & \multicolumn{1}{c|}{ C1 } & C2 & C3 \\
\hline Aceh & Area Permintaan Besar & & \\
\hline Aceh Barat & Area Permintaan Besar & & \\
\hline Aceh Besar & Area Permintaan Besar & & \\
\hline Aceh Jaya & Area Permintaan Besar & & \\
\hline
\end{tabular}

Tabel 1.15 Hasil Proses K-Means (Lanjutan)

\begin{tabular}{|c|c|c|c|}
\hline Area & C1 & $\mathrm{C2}$ & C3 \\
\hline Aceh Selatan & Area Permintaan Besar & & \\
\hline Aceh Singkil & Area Permintaan Besar & & \\
\hline Aceh Tamiang & Area Permintaan Besar & & \\
\hline Aceh Tengah & Area Permintaan Besar & & \\
\hline Aceh Tenggara & Area Permintaan Besar & & \\
\hline Aceh Utara & Area Permintaan Besar & & \\
\hline Asahan & & Area Permintaan Sedang & \\
\hline Banda Aceh & & & Area Permintaan Kecil \\
\hline Batu Bara & Area Permintaan Besar & & \\
\hline Belawan & Area Permintaan Besar & & \\
\hline Bener Meriah & Area Permintaan Besar & & \\
\hline Binjai & Area Permintaan Besar & & \\
\hline Bireuen & Area Permintaan Besar & & \\
\hline Dairi & Area Permintaan Besar & & \\
\hline Deli Serdang & & Area Permintaan Sedang & \\
\hline Gayo Lues & Area Permintaan Besar & & \\
\hline Humbang Hasundutan & Area Permintaan Besar & & \\
\hline Karo & & Area Permintaan Sedang & \\
\hline
\end{tabular}




\begin{tabular}{|l|l|l|l|}
\hline Kota Medan & & Area Permintaan Sedang & \\
\hline Labuhan Batu & Area Permintaan Besar & & \\
\hline Labuhan Batu Utara & Area Permintaan Besar & & \\
\hline Langkat & & Area Permintaan Sedang & \\
\hline Langsa & Area Permintaan Besar & & \\
\hline Lhokseumawe & Area Permintaan Besar & & \\
\hline Nagan Raya & Area Permintaan Besar & & \\
\hline Pakpak Barat & Area Permintaan Besar & & \\
\hline Pidie & Area Permintaan Besar & & \\
\hline Pidie Jaya & Area Permintaan Besar & & Area Permintaan Kecil \\
\hline Samosir & Area Permintaan Besar & & \\
\hline Serdang Bedagai & & & \\
\hline Siantar & & Area Permintaan Sedang & \\
\hline Sibolga & Area Permintaan Besar & & \\
\hline Sigli & Area Permintaan Besar & & \\
\hline Simalungun & & Area Permintaan Sedang & \\
\hline Subulussalam & Area Permintaan Besar & & \\
\hline Tanjung Balai & Area Permintaan Besar & & \\
\hline
\end{tabular}

Keterangan :

Klusterisasi untuk area permintaan barang atas sampel item rokok berdasarkan data yang diperoleh dari PT Indomarco Prismatama Cab.Medan untuk pusat cluster pertama dinyatakan ada 31 kategori area permintaan barang dengan kondisi area permintaan besar. Sedangkan untuk pusat cluster kedua dinyatakan ada 7 kategori area permintaan barang yang sedang dan pada pusat cluster ketiga dinyatakan ada 2 kategori area permintaan barang yang kecil.

\section{BENTUK INTERFACE APLIKASI}

1. Interface Form Menu Utama

Menu utama merupakan tampilan awal setelah berhasil login ke sistem. Menu pada menu utama masih belum dapat diakses apabila pengguna belum melakukan login ke sistem. Dalam form menu utama terdapat menu data, menu proses, menu menampilkan laporan, serta menu keluar dari aplikasi. Berikut ini adalah tampilan form utama beranda :

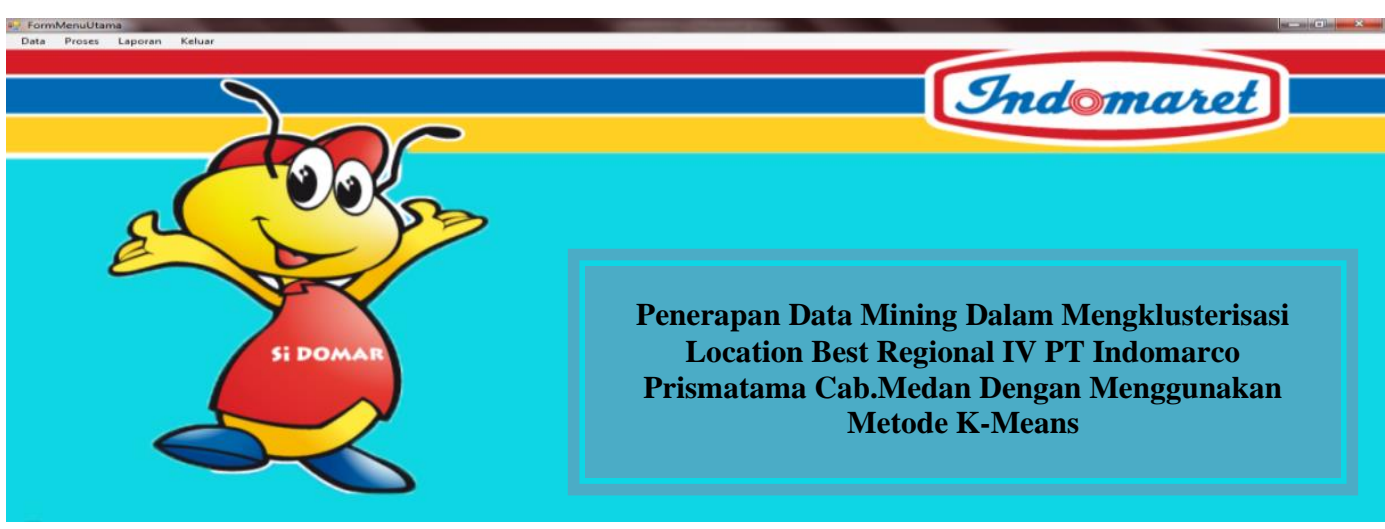

Gambar 1.2 Tampilan Interface Form Menu Utama

2. Interface Form Permintaan Barang

Form permintaan barang merupakan form yang digunakan untuk menampilkan data permintaan barang, yang meliputi id, nama area, jumlah toko, dan jumlah item. Pada form permintaan barang terdiri 5 (lima) buah tombol button yaitu tambah, edit, bersih, hapus, dan batal. Adapun tampilan form permintaan barang adalah sebagai berikut :

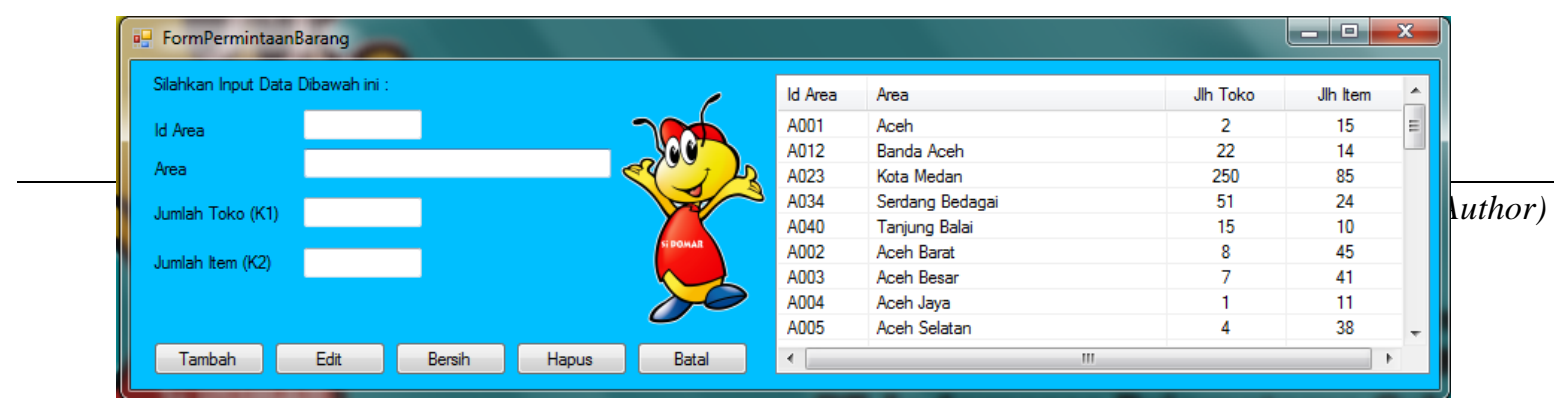


3. Interface Form Centroid

Gambar 1.3 Tampilan Interface Form Permintaan Barang

Berikut ini terdapat data permintaan barang yang digunakan untuk menentukan titik cluster awal yang telah diinisialisasi, yang nantinya digunakan dalam perhitungan $k$-means. Kemudian terdapat tiga button yang digunakan sebagai perintah untuk melakukan pengolahan data seperti simpan, batal, dan keluar form.

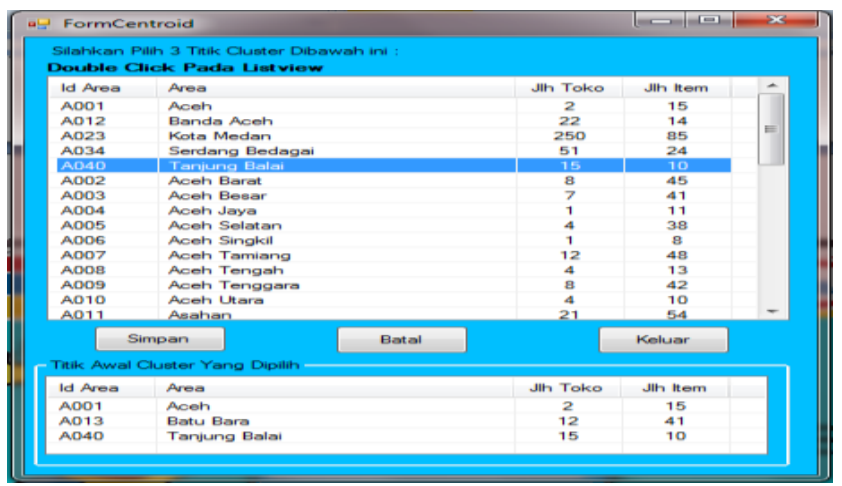

Gambar 1.4 Tampilan Interface Form Centroid

4. Tampilan Interface Form K-Means

Pada form tersebut terdapat listview titik cluster yang telah dipilih pada form centroid sebelumnya, listview anggota cluster 1, listview anggota cluster 2, dan listview anggota cluster 3 dari masing-masing iterasi dan kesimpulan dari hasil perhitungan K-Means. Kemudian terdapat tiga buah button yaitu proses, batal dan keluar form yang masing-masing digunakan untuk melakukan proses perhitungan metode $K$-Means, membatalkan proses perhitungan, serta menutup form. Berikut tampilan interface form K-Means.

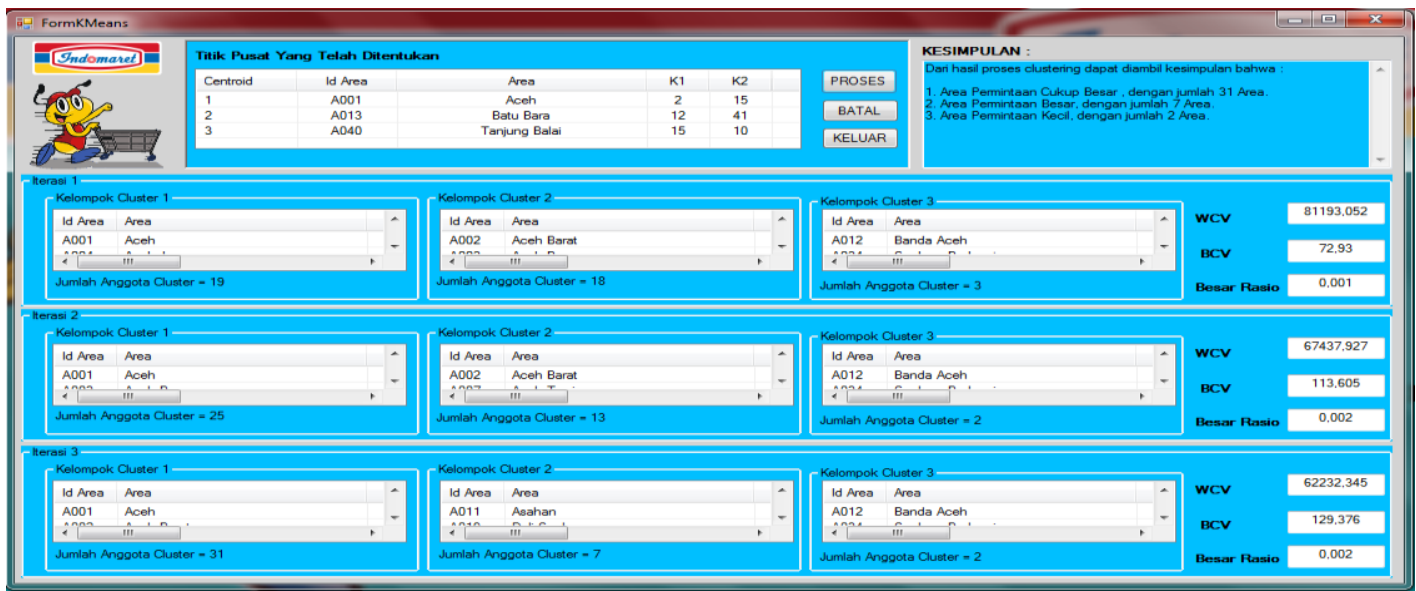

Gambar 1.4 Tampilan Proses K-Means

5. Tampilan Form Laporan

Laporan ini berfungsi untuk menampilkan hasil dari pengelompokan data permintaan barang yang telah dihitung melalui form K-Means. Adapun tampilan dari form laporan adalah sebagai berikut : 


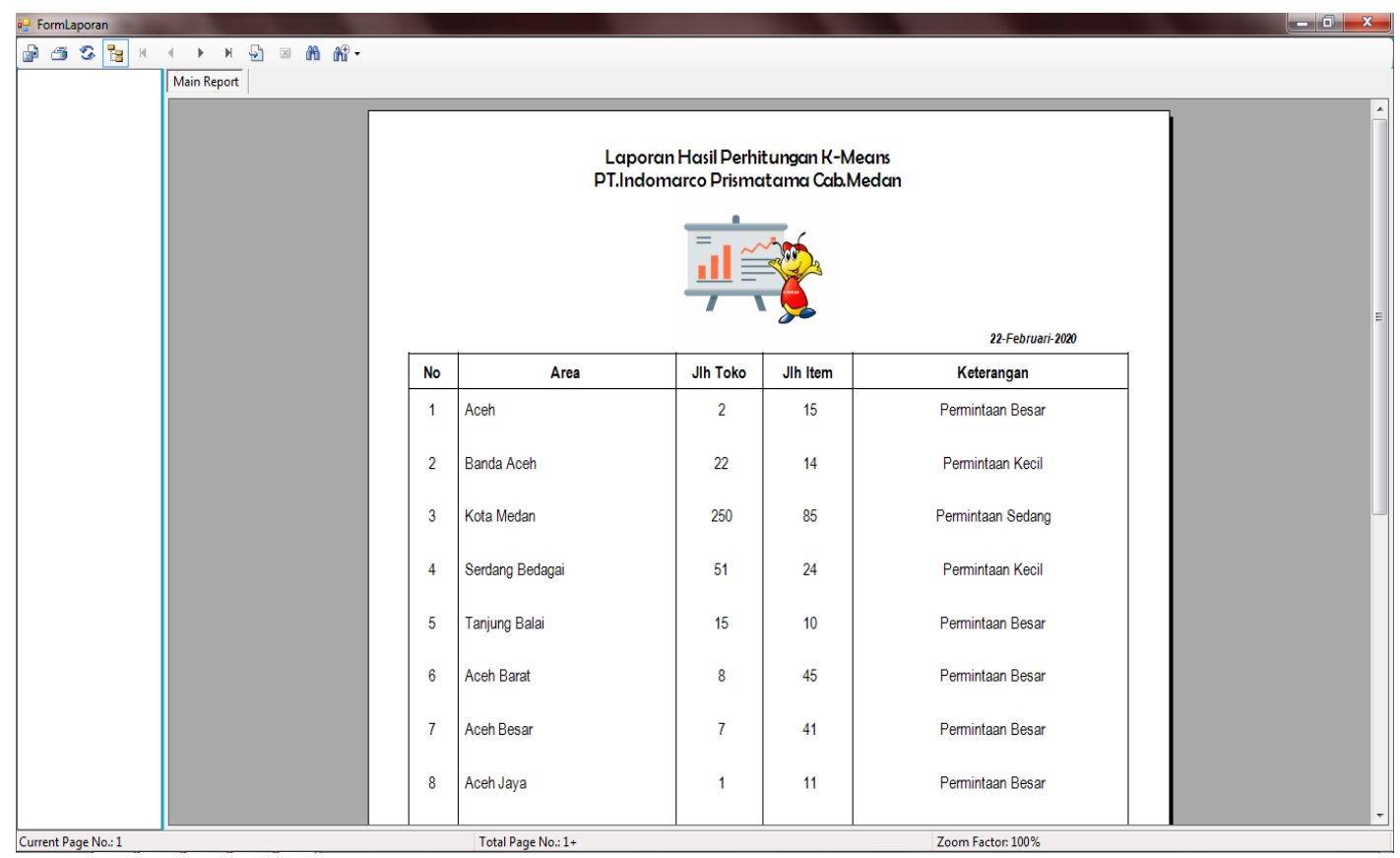

Gambar 1.6 Laporan Hasil Pengelompokan Data Permintaan Barang

\section{KESIMPULAN}

Berdasarkan hasil uraian analisa dan pengujian perancangan pada bab sebelumnya, kesimpulan yang dapat diambil adalah sebagai berikut :

1. Berdasarkan analisis masalah yang terjadi dalam klusterisasi area mana yang memiliki permintaan produk yang besar dapat dianalisis mengunakan sebuah ilmu pengetahuan yaitu berupa penerapan data mining dalam membantu pemecahan masalah yang terjadi pada penelitian ini dan berdasarkan hasil penelitian, dalam penerapan data mining yang mengadopsi metode K-Means Clustering dapat digunakan dalam penyelesaian masalah PT Indomarco Prismatama Cab.Medan.

2. Berdasarkan hasil analisa, penerapan K-Means Clustering diawali dengan menentukan titik pusat awal centroid yang kemudian digunakan untuk mencari jarak terdekat dari setiap masing-masing data yang selanjutnya digunakan dalam mencari iterasi dan cluster, yang dihitung dengan konsep sebuah iterasi secara berulang untuk mendapatkan sebuah nilai rasio dimana akan dihentikannya perhitungan iterasi ketika nilai rasio tidak lagi lebih besar dari nilai rasio sebelumnya. Maka dilakukan pembentukan kesimpulan pengetahuan baru bagi perusahaan dalam bentuk tabel dengan cara mengurutkan data dari area permintaan paling besar sampai dengan area yang paling kecil dan dalam penelitian ini iterasi dihentikan pada iterasi ke tiga.

3. Berdasarkan hasil implementasi sistem dalam penerapan data mining menggunakan metode $K$-Means Clustering, metode ini mampu dalam pengimplementasiannya kedalam aplikasi dan dapat berjalan dengan baik dan mampu juga menyimpulkan hasil dari penelitian dalam menentukan area mana yang memiliki permintaan dari paling besar hingga paling kecil.

\section{REFERENSI}

[1] M. Hasanah, S. Defit, and G. W. Nurcahyo, "Implementasi Algoritma K-Means untuk Klasterisasi Peserta Olimpiade Sains Nasional Tingkat SMA,” J. Sistim Inf. dan Teknol., vol. 1, no. 3, pp. 31-36, 2019.

[2] E. Irfiani and S. S. Rani, "Algoritma K-Means Clustering untuk Menentukan Nilai Gizi Balita," J. Sist. dan Teknol. Inf., vol. 6, no. 4, p. 161, 2018.

[3] Y. Darmi and A. Setiawan, "Penerapan Metode Clustering K-Means Dalam Pengelompokan Penjualan Produk," vol. 12, no. 2, pp. 148-157, 2016.

[4] F. M. Firman Nurdiyansyah, Samsul Arifin, "Clustering algorithm untuk pengelompokan pelanggan 
dalam bidang usaha server reload," Semin. Nas. Sist. Inf., pp. 1043-1047, 2018.

[5] L. Bruno, "Implementasi Data Mining Pemilihan Pelanggan Potensial Menggunakan Algoritma KMeans," J. Chem. Inf. Model., vol. 53, no. 9, pp. 1689-1699, 2019.

[6] S. Pai, F. Di Troia, C. A. Visaggio, T. H. Austin, and M. Stamp, "Clustering for malware classification,” J. Comput. Virol. Hacking Tech., vol. 13, no. 2, pp. 95-107, 2017. 